\title{
A Prayer for Katerina Horovitzova (Modlitba pro Kateřinu Horovitzovou)
}

Author: Arnošt Lustig

First Published: 1964

Translations: Slovak (Modlitba pre Katarínu Horovitzovú, 1965); Bulgarian (Molitva za Katerina Chorovic, 1967); Estonian (Hingepalve Katarzyna Horowitzi eest, 1967); Hebrew (Tefílá 'al Káteríná Hóróbis, 1967); Japanese (Shojo Katezina no tame no inori, 1967); Norwegian (En bønn for Katarina, 1967); Croatian (Molitva za Katarinu Horovic, 1971); English (A Prayer for Katerina Horovitzova, 1973); German (Ein Gebet für Katharina Horowitzová, 1991); Dutch (De reis van Katharina Horowitz, 1994); Serbian (Molitva za Katarinu Horovic, 2002); French (La danseuse de Varsovie. Prière pour Katarzyna Horowitz, 2012); Spanish (Una oración por Kateřina Horovitzová, 2012).

Theatre Adaptations: Terezínské divadlo, Theresienstadt (2011); Divadlo pod Palmovkou, Prague (2012).

Film Adaptation: Modlitba pro Kateřinu Horovitzovou (A Prayer for Katerina Horovitzova); TV film, screenplay Arnošt Lustig and Antonín Moskalyk, film director Antonín Moskalyk, premiered 1967.

About the Author: Arnošt Lustig (1926-2011) was born into a middle-class Czech-Jewish family in Prague. In 1941 he was expelled from secondary school because he was a Jew. In 1942, his family was sent to the Theresienstadt Ghetto, from where in September 1944, they were deported to Auschwitz-Birkenau. His father was gassed there. Arnošt, his mother, and sister survived. Lustig was taken to Buchenwald and then, in April 1945, he escaped from a train carrying him to the Dachau concentration camp. This experience inspired his short story Darkness Casts No Shadow in the book $\rightarrow$ Diamonds of the Night. He returned to Prague in time to take part in the May Uprising against the Nazi occupation in 1945.

After the war, Lustig became a member of the Communist Party. He studied at the School of Political and Social Sciences in Prague (completing his studies in 1950) and worked as a journalist in newspapers, magazines and at Radio Prague. He reported on the Arab-Israeli War from 1948 to 1949. From 1961 to 1968 Lustig was a scriptwriter for the state Barrandov Film Studio. In June 1967, Lustig and other Czech writers supported Israel in the Six-Day War against Egypt and Syria, and so they came into conflict with Communist leadership which condemned Israel as the "aggressor". Following the Soviet-led invasion in August 1968, he left Czechoslovakia, first to Israel, and later in 1970, to the United States where he taught, mostly in Washington D.C. at the 
American University, giving lectures on creative writing, film and literature. After the Velvet Revolution in 1989, he divided his time between Prague and the U. S.

Apart from a few stories, the Holocaust was the subject of Lustig's writing the whole time. His first works were among his best. They included the short stories Night and Hope, and $\rightarrow$ Diamonds of the Night. Lustig's stories often thematised the fate of beautiful Jewish girls or young women in prison camps (A Prayer for Kateřina Horovitzová, The Unloved, Colette, Lovely Green Eyes etc.). It is typical for his later works that the author adapted and expanded his earlier texts, their original introspective and laconic character changing to a contemplative, verbose style.

Further Important Publications: Noc a naděje (1958, Night and Hope; short stories); Démanty noci (1958, $\rightarrow$ Diamonds of the Night; short stories); Dita Saxová (1962, Dita Saxová; novella); $Z$ deníku sedmnáctileté Perly Sch. (1979, From the Diary of Perla Sch., Seventeen Years Old; later under the title Nemilovaná, The Unloved; fictional diary); Colette: Dívka z Antverp (1992, Colette: A Girl from Antwerp; novella); Krásné zelené oči (2000, Lovely Green Eyes; novel).

\section{Content and Interpretation}

The novella was inspired by actual events which took place in Auschwitz in October of 1943 - the murder of a group of rich Jews whom the Nazis had promised safe passage across the border for a high price. A young woman among these Jews, the Polish-Jewish dancer Franciszka Rosenberg-Manheimer (artistic name Lola Horowitz), shot the German SS Rapportführer Josef Schillinger who was known for his cruelty and who had humiliated her. This true story (see Müller, 1979; Amman, Aust, 2013), which was disseminated among Auschwitz prisoners, was adapted by several authors, among others, Tadeusz Borowski ( $\rightarrow$ A Farewell to Maria) in the short story The Death of Schillinger in his The World of Stone (1948).

Arnošt Lustig learned about the story from the former Auschwitz prisoner Erich Kulka, a co-author of the historical account, The Death Factory (in Czech 1946, in English 1966). In Lustig's novella, the protagonists are 20 wealthy Jews with American passports who have returned to Europe after the Allied invasion of Italy in 1943. They were captured by German soldiers and transported to an unnamed concentration camp. High Nazi officer Friedrich Brenske offers to exchange them for captured German officers, if the Jews pay for all the costs. The Jewish prisoners agree. Then they hear a young girl screaming outside: "But I don't want to die...” (Lustig, 2003, p. 119). The group's leader, Herman Cohen, asks Brenske to add the girl, Katerina Horovitzova, to their group. While travelling on a train, Brenske informs Cohen that the authorities do not want to add the girl's name to Cohen's passport because they are not married. Cohen agrees with the formal marriage and they have to return to the camp, which is, according to Brenske, the only place a proper a Jewish wedding can be conducted. After the ceremony, they all once again board the train, which takes them to Hamburg where they are supposed to board a ship, named the Deutschland. 
The members of the group have already drained their bank accounts, having transferred their money to the Germans' accounts. But now the Germans state that they need more money and demand that their American relatives send more. When their relatives refuse, Brenske claims that they will now have to take the train to the Swiss border where the exchange will take place. First, however, they must return to the camp, supposedly to be disinfected. Here they receive a towel and a cheap piece of soap; the men begin to disrobe, but Katerina refuses to do so. Schillinger, an arrogant SS officer, insists that she undress and humiliates her. The young woman begins to disrobe, and after she takes off her bra, she hits him with it, takes his gun and shoots him. Then on Brenske's command, the Jewish Sonderkommando, made up of prisoners, forces them all up against the wall where Nazis shoot all the men and Katerina. Rabbi Dajem, imprisoned in the camp, prays for Katerina and the narrator compares her to Judith from the Hebrew Bible.

\section{Main Topics and Problems}

The prose is structured in an extremely complicated way, foregrounding the intelligent Nazi Arthur Brenske who acts like the devilish Mephisto. He does not dominate his victims with brute force, but rather uses sophisticated double-edged talk and promises. For example, he talks about "the final solution" (pp. 161, 213) and the "sundown will take care of everything” (pp. 155-156). The rich Jews gradually prepare their finances saved in American banks for handing-over, hoping that this will help them survive.

\footnotetext{
The final solution is at hand. You'll see for yourselves. Your worries will all go up in smoke and burn away like a brush fire. From my own personal experience, I can testify that people often don't believe things which concern them in the most fundamental way until they feel them on their own skin. [...] We want to liquidate this exchange operation in the best possible way. You must listen to what I'm telling you. Until we've reached a destination which will be satisfactory to everybody and about which you'll have no fault to find, I'm doing my level best to make this trip as pleasant as possible for each and every one of you. (p. 218)
}

The perspective set in the novella is remarkable, since the majority of the situations are viewed through the eyes of the naive American Jews who take a long time to realise that they are nearing their downfall. Meanwhile, the reader, who is receiving additional information, awaits the mercilessly tragic end.

Katerina Horovitzova belongs to a series of young Jewish girls and women in Lustig's works (e.g. Dita Saxová in the novella of the same name; Perla Sch. in The Unloved; Colette). Their beauty, youth and courage form a moving contrast to the horrors of the Shoah. The film version directed by Antonin Moskalyk reduced the number of American Jews down to only six, and stressed the moral dilemma and responsibility of the main characters (Sladovníková, 2018). 


\section{Cited Works}

Amman, T., Aust, S. (2013). Hitlers Menschenhändler. Berlin: Rotbuchverlag. Lustig, A. (2008). Modlitba pro Kateřinu Horovitzovou. A Prayer for Katerina Horovitzova. Tefilá 'al Káteríná Hóróbis. Praha: Nakladatelství Franze Kafky. Müller, F. (1979). Eyewitness Auschwitz: Three Years in the Gas Chambers. New York: Stein and Day Publishers. Sladovníková, Š. (2018). The Holocaust in Czechoslovak and Czech Future Films. Stuttgart: ibidem, pp. 52-55.

\section{Further References}

Bauer, M. (2003). Ani zapomenout, ani odpustit. In: A. Lustig, Modlitba pro Kateřinu Horovitzovou. Praha: Andrej Štastný, pp. 131-155. Firlej, A. (2016). W cieniu Zagłady. Poznań: Adam Mickiewicz University. Haman, A. (2001). Arnošt Lustig. In: S. Serafin, ed., Twentieth-Century Eastern European Writers. Detroit: The Gale Group, pp. 233242. Holý, J. (2010). Arnošt Lustig: Modlitba pro Kateřinu Horovitzovou. In: R. Ibrahim, ed., Interpretace textů. Praha: Akropolis, pp. 88-100. Pynsent, R. (2004). Arnošt Lustig. In: E. Sicher, ed., Holocaust Novelists. Detroit: The Gale Group, pp. 220-226. Trucks, R. (1999). A Conversation with Arnošt Lustig. New England Review, 20(14, Spring 1999), pp. 68-77. Vohryzek, J. (1995). Literární kritiky. Praha: Torst, pp. 143146.

$\mathrm{JH}$ 